\title{
The lj-plein: Housing At The Threshold of Urban Policies
}

\author{
Esen Gökçe ÖZDAMAR
}

\section{Introduction}

The IJ-plein in the north of Amsterdam is an example of a cinematic dialogue between the observer and a fragmented urban narrative. The IJ-plein, being the first work of the Office for Metropolitan Architecture (OMA) waterfront residential development forms its narrative through creating strategies in structuring the center and the periphery of the city in a time when turnabout in urban policies were shaping Amsterdam. The IJ-plein is one of the signs of today's and major residential waterfront areas and can be read regarding its spatio-temporal context (Figure 1).

There is a relationship between the condition of Koolhaas's buildings and their environment: the buildings are not passive wrappings that are viewed, but are imageless spaces viewing their visitors, awaiting questions on the potentiality of the space. The IJ-plein is more like an observer looking towards the historical centre, distant from engaging with the environment. This can be interpreted by the meaning of its enclosed narrative. The settlement stays reluctant and in a critical point in a time of change in urban policies. As such, the question arises: What particular relationship does the IJ-plein have with the dynamics of the rhizome city of Amsterdam ? ${ }^{1}$

In Amsterdam, the northern part of the IJ banks was developed in the early 1980s. Koolhaas and OMA were appointed to develop strategies for the IJ-plein waterfront and transform it into a residential suburb in 1981-1988 along with six other architects (Chris- tiaanse, 2003). The plan was developed by various architects from seven architectural firms with allocations "according to 22 classic systems devised by architects including Le Corbusier, Jan Duiker and Lotte StamBeese". Here OMA created two patterns consisting of urban character and villas in the western and eastern parts. ${ }^{2}$ The polder area had been an industrial fringe area before the bankruptcy of the Amsterdam Dry Dock Company (Amsterdamse Droogdok Maatschappij) (Figures 2-6). Following policies for a more compact city, the municipality of Amsterdam opened the old docklands and shipyards to regeneration, replacing the former overspill policy. The 1985 Structure Plan of Amsterdam suggested that waterfront redevelopment along the IJ would help meet the city's housing challenge and attract people from all income groups. Kool-

\footnotetext{
1 Deleuze and Guattari define Amsterdam as a city of rhizome-a city of extension-with different canals developing through a single centre and rings around the centre. According to them, a rhizome represents multiple overlapping potentialities and extensions; it is an anti-structure. Some cities have a rhizomatic genesis or formation with their undetermined extensions and potential to create new forms (Deleuze and Guattari, 1987, p. 21). As a reading of Deleuze and Guattari, Arie Graafland defines Amsterdam as involving traditional Dutch houses arrayed around ring canals and Berlage houses that display an experimental approach (Graafland 2000, p. 105). The centre of Amsterdam has a historical rhizome pattern with contemporary extensions that began with policy changes in the 1980s. After the 1990s, Amsterdam transformed into a multi-centred city. These policy changes reinforced the rhizome pattern of the city. These plans are separate from the Amsterdam Extension Plan of 1935 and include the current Amsterdam 2003-2015 plan. Key terms in this planning include compact city, transformation, regional perspective, and strategic intervention. In addition, there is emphasis on the city's extensions.

2 Anon (a). 2014.
}

Department of Architecture, Namık Kemal University Faculty of Fine Arts, Design and Architecture, Tekirdag, Turkey.

Article arrival date: January 11, 2015 - Accepted for publication: August 11, 2015

Correspondence: Esen GÖKÇE ÖZDAMAR. e-mail: gokceozdamar@hotmail.com

○ 2015 Yıldız Technical University, Faculty of Architecture 


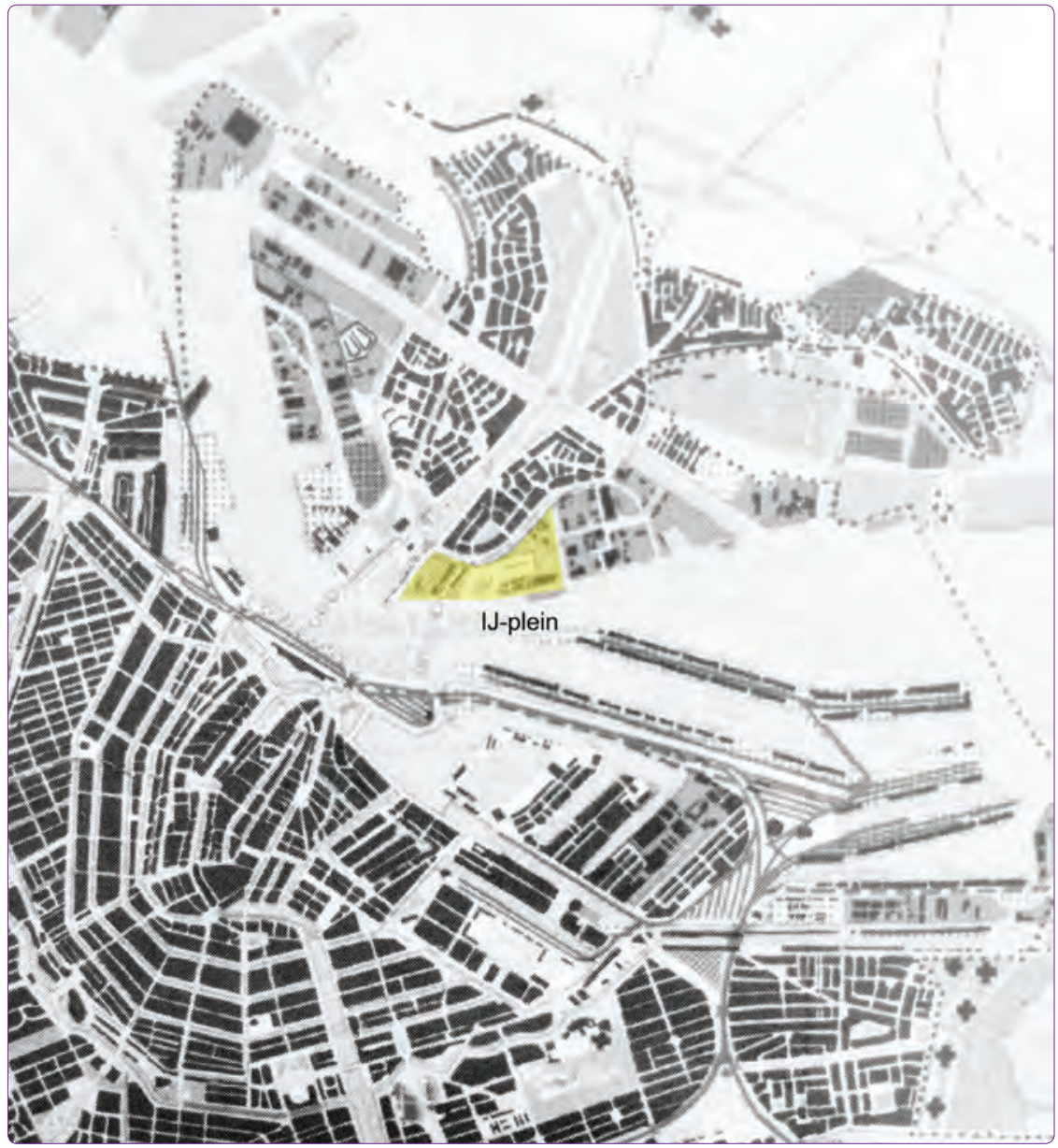

Figure 1. Amsterdam General Extension Plan (AUP) and IJ-plein, 1935 (Source: Jolles, A. (2003) Planning Amsterdam: scenarios for urban development, 1928-2003, Rotterdam, NAI Publishers, p. 84-85).

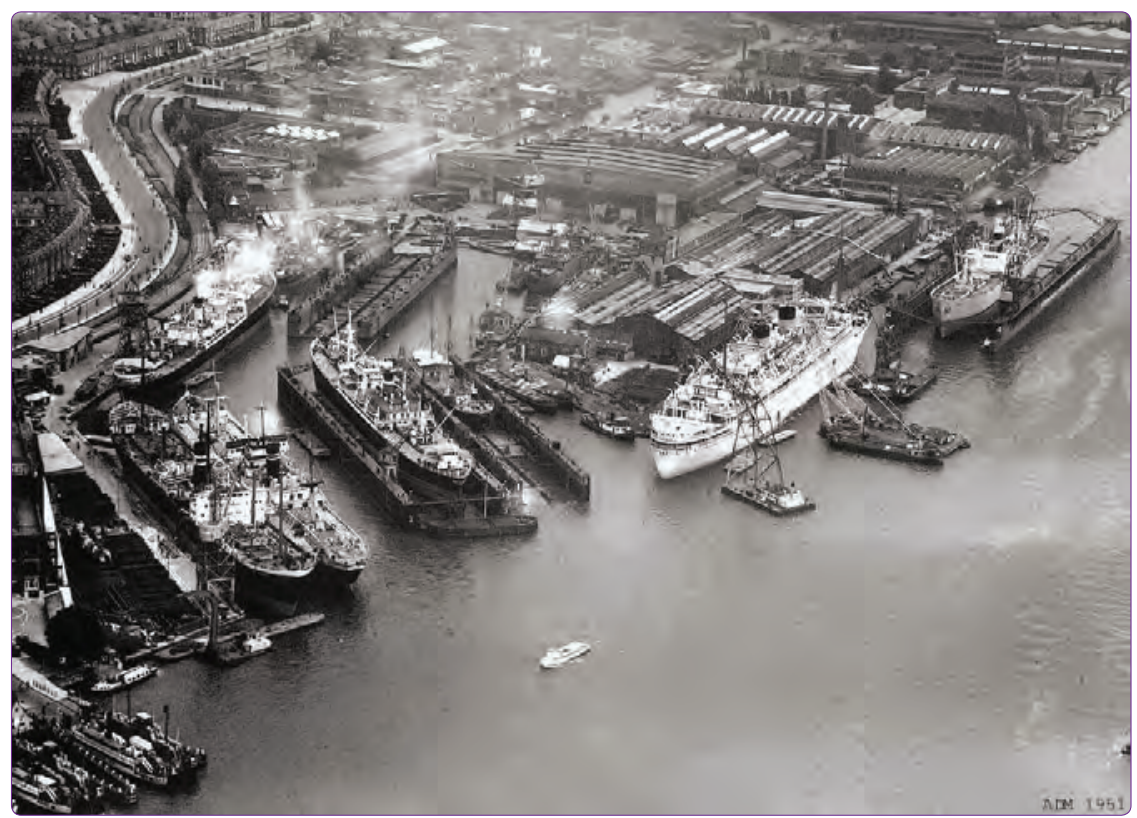

Figure 2. Historical Development IJ-plein, 1951 (http://www.ndsm-werfmuseum.nl/dewerven/adm). 


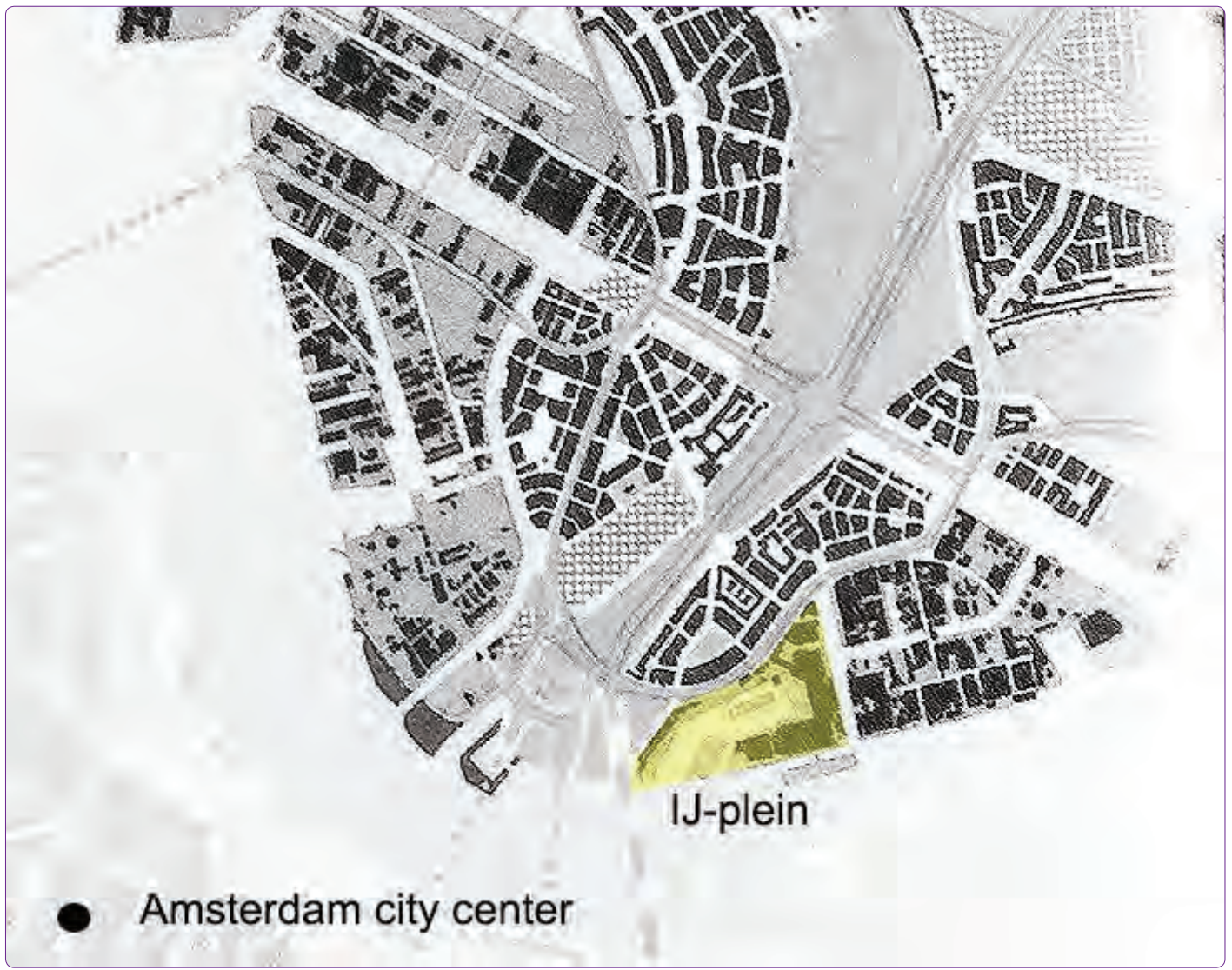

Figure 3. From Structure Plan for the urban area to the north of the IJ, 1958 (Source: Jolles, A. (2003) Planning Amsterdam: scenarios for urban development, 1928-2003, Rotterdam, NAI Publishers, p. 86-87).

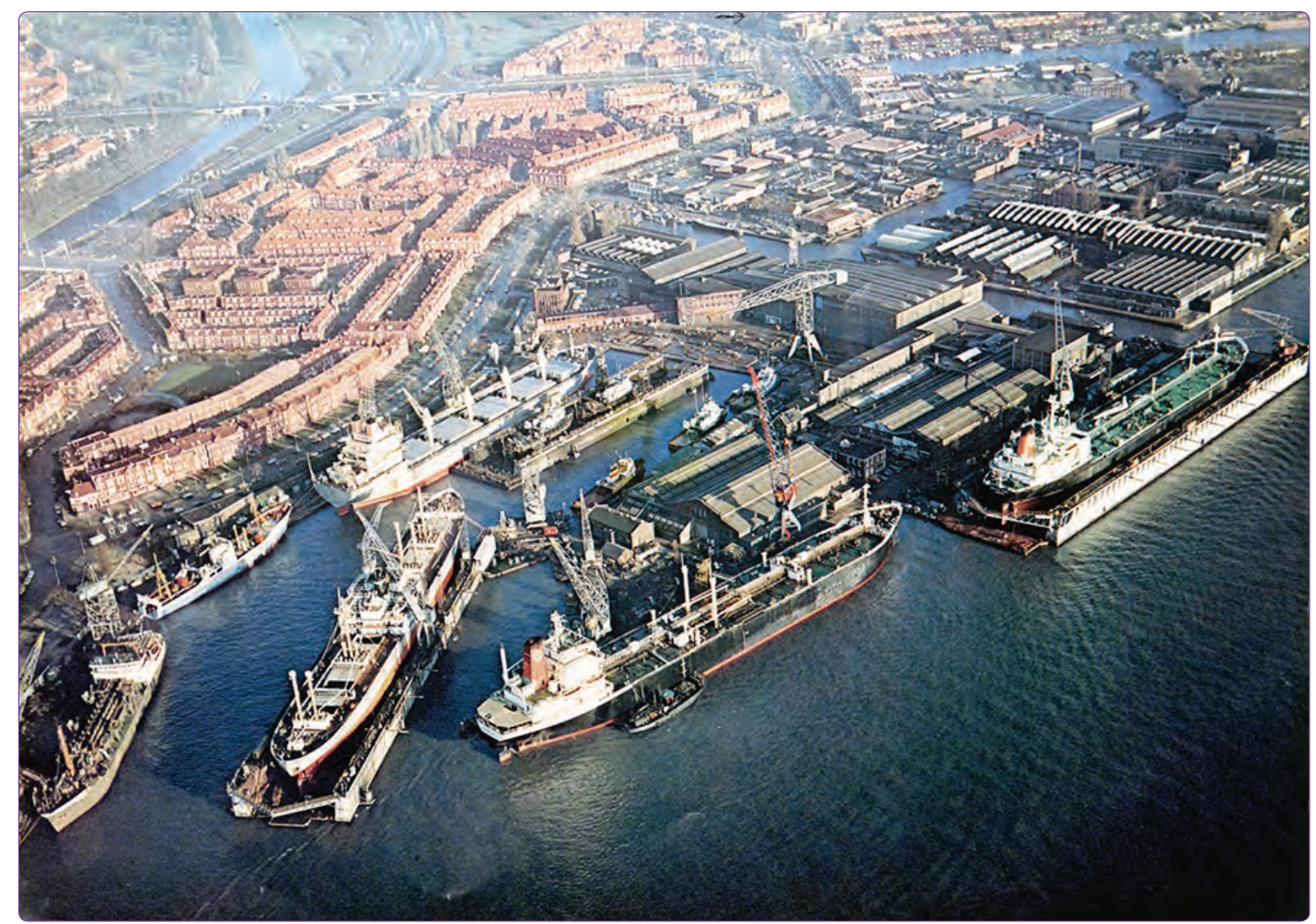

Figure 4. Historical Development IJ-plein, 1976 (http://www.ndsm-werfmuseum.nl/de-werven/adm). 


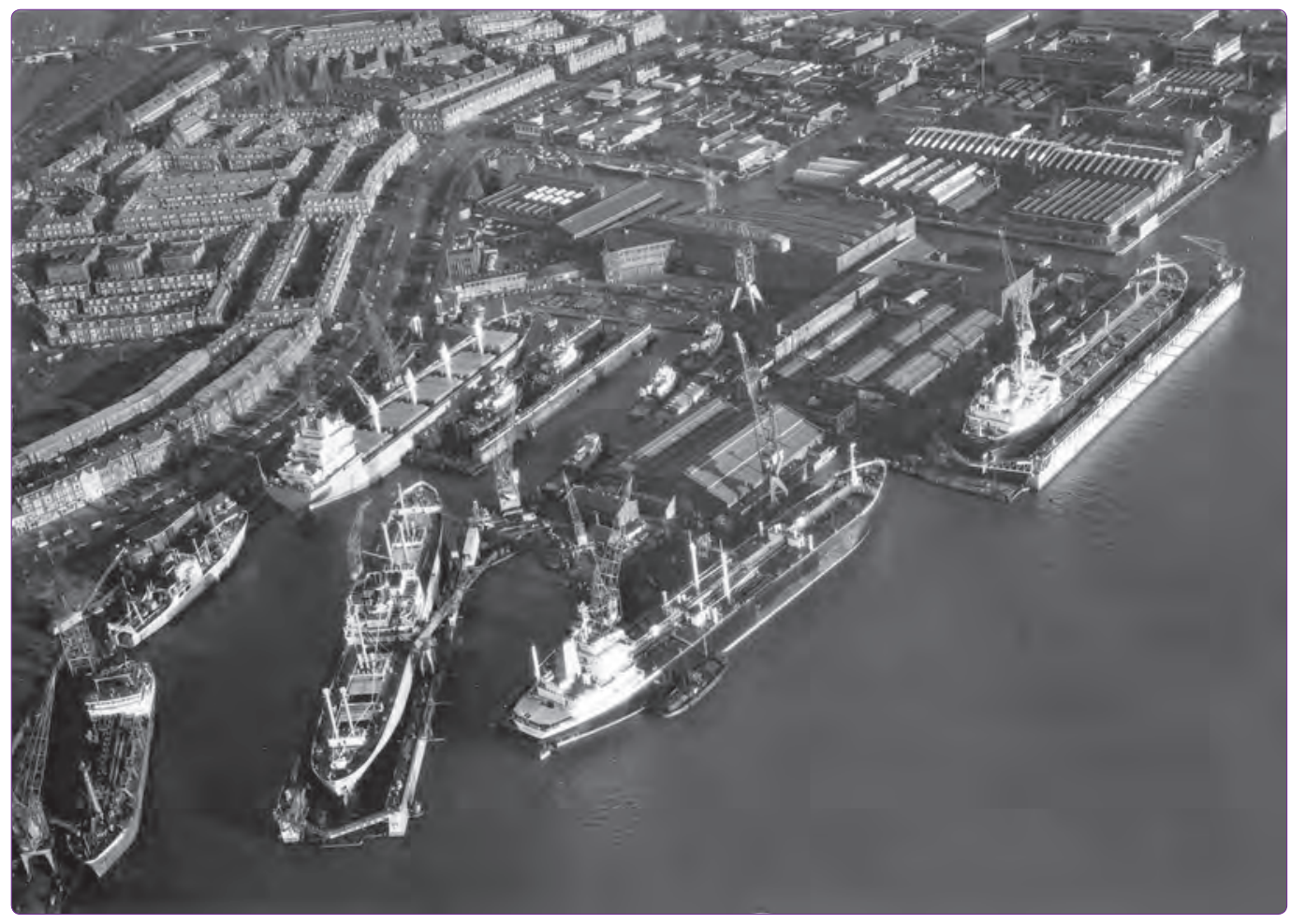

Figure 5. Historical Development IJ-plein, 1977 (http://www.ndsm-werfmuseum.nl/de-werven/ adm).

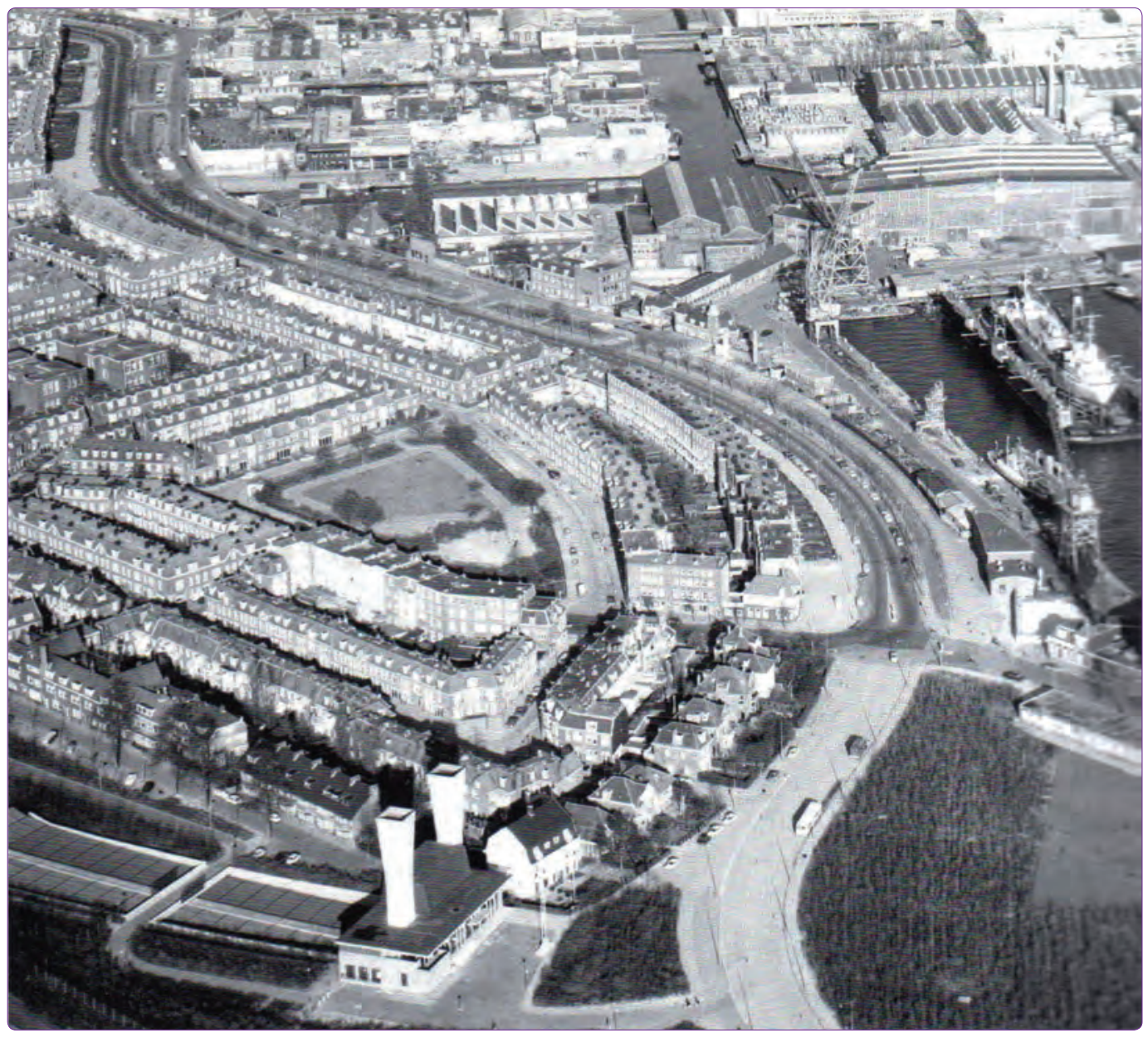

Figure 6. Vogelbuurt area before construction of housing on the IJ-plein, 1970s (Source : Jolles, A. (2003) Planning Amsterdam: scenarios for urban development, 1928-2003, Rotterdam, NAl Publishers, p. 146). 
haas and OMA's plan aimed to accommodate as many urban functions as possible within a compact urban plan. "The intention of OMA was to increase density in the area with high-rise buildings. This was rejected by a veto of the local residents, who had considerable influence on the programme." ${ }^{3}$

Within this design, OMA reintroduced the urban villa concept in a layout that was civil and taboo, according to the CIAM. ${ }^{4}$ Koolhaas mentioned that he derived his ideas from the traditions of the more pragmatic north. The scheme included recreational facilities, a community centre, a school, and a gym distributed in different urban typologies. He referenced the previous industrial layout of the former harbour basin. This determined some of the orientations and implementations with allotment gardens and drainage ditches, which are traditional in Dutch landscaping. He interfered with planting, the colour of the asphalt, playing fields, and allotment strips perpendicular to the IJ, leaving the sightlines of the water and the city to remain open. ${ }^{5}$ The plan consisted of two neighbourhoods: four-storey urban apartments in the western part and low-rise blocks in the eastern part, with narrow streets arranged perpendicular to the waterfront. The eastern part of the IJ-plein is a cross between a garden village and Siedlung Römerstadt Ernst May in 1927-1928 made for Frankfurt am Main. 'The western part is a variation on the Stadt ohne Höfe (City without Farms), a combination of long blocks and urban villas, an urban model developed by the Luckhart Brothers and Alfons Anker in Berlin in 1927. After the reintroduction, Koolhaas's urban villa became popular in the Netherlands. ${ }^{6}$ OMA's plan for the IJ-plein became a cinematic experience made up of frames - a moving observer (to experience the changing spaces) and an "image" (by increasing activities as actors within them). His apartment block, raised on pilotis, follows the form of the Corbusian machine house. In the IJplein, OMA's analysis and concept are completely fused, with fragmented typologies and activities that take place in the area, which is called a cold assembly. Koolhaas suggests this assembly is intended to evoke tension through a composition comprised of different fragments. Here, montage becomes a node point with the potential to articulate emerging narratives in Amsterdam (Figures 7-9). ${ }^{\text {? }}$

\footnotetext{
3 Christiaanse, 2003, p. 5.

4 van den Boomen, 2002.

6 van den Boomen, 2002.

Anon (b). 2014.
}

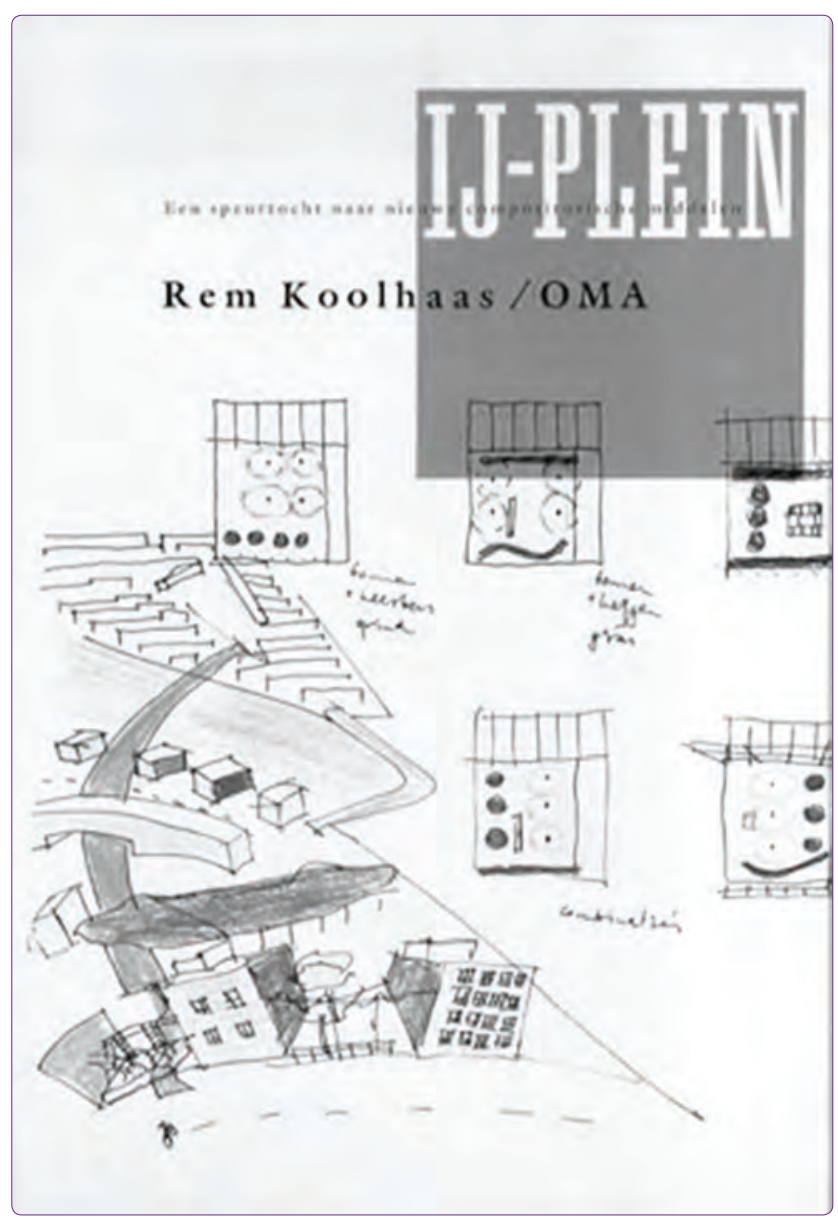

Figure 7. A sketch of the IJ-plein by Koolhaas (Source: http:// bernardleupenhome.blogspot.com.tr/).

\section{Reluctant with the Rhizomatic Amsterdam}

During the construction process of the IJ-plein, Vinex policies (1988) were being implemented. At that time, there was a shift in housing policy from social housing to the commercial market, seeking a competitive and innovative design approach with a focus on process planning. These policies foregrounded the implementation of a compact city. Industrial peninsulas were transformed into residential neighbourhoods with private homes and luxury homes to keep highincome groups from leaving the city. The public-sector housing that was valid until the end of the 1980s was transformed into a free-market model that demanded a more pragmatic "use" of the waterfront by providing high density, which is observed in the planning process of the Eastern Harbour District (Schaap, 2003). The IJplein signalled a need for change. Moreover, Bijlmermeer's unsuccessful attempt played an important role in shaping new approaches for the planning of the following IJ neighbourhood docklands and artificial islands: Borneo-Sporenburg, Java, KNSM, and later IJ- 


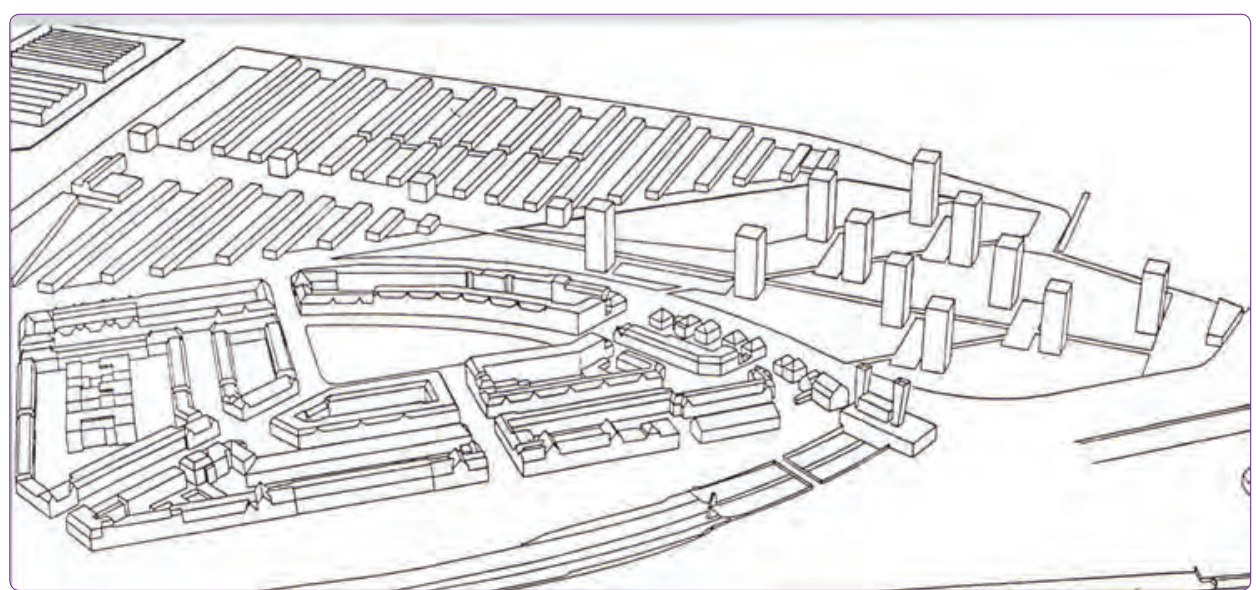

Figure 8. Bird's eye view of the draft plan by OMA, 1980 (Source: Jolles, A. (2003) Planning Amsterdam: scenarios for urban development, 1928-2003, Rotterdam, NAI Publishers, p. 145).
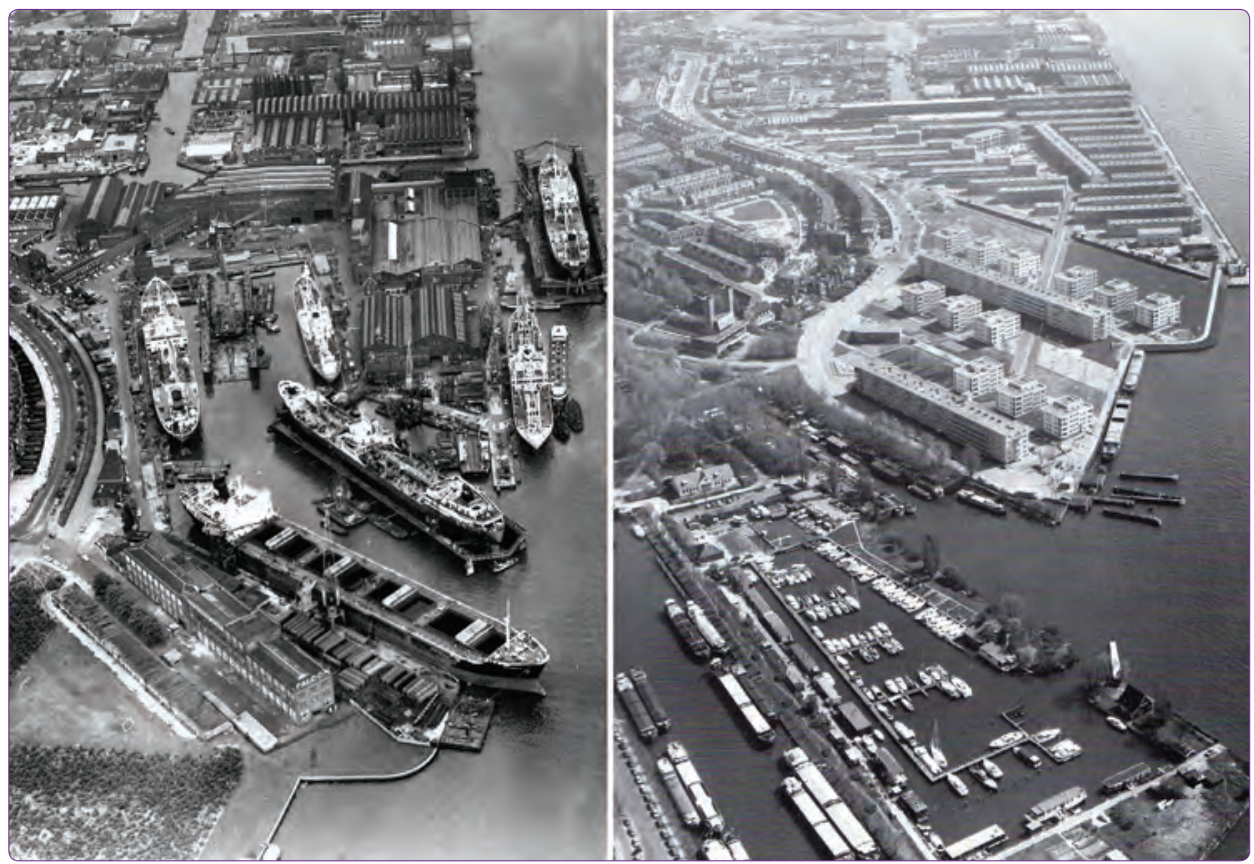

Figure 9. Area in 1977 and 1987 after OMA's plan (Source: http://www.ndsm-werfmuseum.nl/ de-werven/adm, and Jolles, A. (2003) Planning Amsterdam: scenarios for urban development, 1928-2003, Rotterdam, NAI Publishers, p. 147).

$\operatorname{burg}^{8}$ (Schaap, 2003, p. 51). These islands were divided into long allotments for experimental containers and boat houses as an extension of this lived experience in-

\footnotetext{
8 The following 1989 Policy Document on Basic Principles (Nota van Uitgangspunten, $\mathrm{NvU}$ ) raised questions regarding "What is the structure to be?" and "How is building to take place?" Additionally, the turnabout in politics, when the Amsterdam City Council changed in 1986, resulted in a free market approach. This was epitomised when 'building for the neighbourhood' became "building for the market." This stimulated private housing and luxury rental houses; mixing market and social sectors became the new policy (Anon (c), 2014). The plan for these islands, especially the KNSM island, was first inspired by OMA's plan for "open parcel allotment in various angles in the dock." This was the opposite of the plan by the DRO (Spatial Planning Department) (Schapp, 2003, p. 50).
}

spired by the old historic city of Amsterdam. However, the waterfront of Amsterdam was interrupted by 1889 built Central Station. The waterfront sites near the city core were developing towards east, west and firstly to the north (Gastil, 2002). This breakthrough resulted as negativity was observed in the planning of the Eastern Docklands and ljburg.

These islands are characterised by open parcel allotments in which the building strips are positioned at various angles in relation to the dock. This facilitates a view of the south dock and the water from the main roadways in the centre of the islands, not from the 
flats. The DRO opposed to this plan which was predicated on large residential buildings along the docks. Berlage's Plan-zuid served as the inspiration for the first design by the DRO. ${ }^{9}$ The KNSM island was planned at the same time the IJ-plein was constructed; the flats had to view the sea as much as possible. For the design of the Eastern Docklands, a Housing Atlas was formed to provide schemes and variations of different typologies. The Housing Atlas became a node point in creating diverse forms and programs, ranging from single apartments to family homes and high-density blocks that provided mixed-use strategies. These variations provided rhythmic repetitions in change, like extensions in movement, creating an extension of the rhizomatic city centre. ${ }^{10}$ Even when Soeterds designed the seemingly same pattern in Copenhagen, there is a slight difference in the use of facade, such as the glass proportion of the facade slightly and relatively bigger in comparison. However, the same repetition does not enable its being rhizomatic pattern. Koolhaas's pattern is overdesigned, and pragmatic, yet humanistic.

According to Christiaanse, the IJ-plein is characterised "by an urban sensibility and typological inventiveness, most harbour areas from that period have a mono-culture of housing and a "step-mother" relationship with the water. ${ }^{11}$ However, Graafland defines that IJ-plein fails in creating a lively urban space through its garden city tradition in a strategic waterfront location, causing vast open spaces with its low density of 86 dwellings/ha in comparison to the following highdensity row housing projects of the 1990s, such as Borneo-Sporenburg and its large mono-functional. ${ }^{12}$

In the IJ-plein, however, before the Eastern Docklands, OMA formed its own Housing Atlas, a montage with a set of 'layers' that demonstrated the physical conditions and fragmentation of urban models, programs, activities, and images, leading to a cinematic experience. The IJ-plein views the IJ river in Amsterdam as an observer and projects signals of what is changing in the environment. Koolhaas's work here, being a "pragmatic" rhizome, becomes a perpetual and stable space overlooking the city. In contrast to the Eastern Docklands, Koolhaas has designed a 'universal genius loci' in the IJ-plein, resembling a remarkable landmark separate from the marketable image of the Harbour District. He has constructed a symbol here that creates a micro-interplay with urban fragments in itself, which awaits the changing environment and

\footnotetext{
9 Buurman, 2003, p. 58.

10 Özdamar, 2011, p. 128.
${ }^{11}$ Christiaanse, 2003, p. 6
${ }^{12}$ Graafland, 2012, p. 95.

transitions through policy turnovers. Goldberger summarises Koolhaas's architecture as follows:

"Koolhaas's urban buildings are not rigid classical structures, defined by a formal order that is fixed and unchanging; they seem in their very being to be in flux, to suggest that while they may look this way today, they might well be turned into something else tomorrow. It is not always the case that Koolhaas's buildings actually realise the generally unrealised modernist dream of total flexibility-they give off the aura of change more often than they possess the reality of it-but it can surely be said that they are designed to be open to social and programmatic evolution." ${ }^{13}$

Koolhaas injects a feeling of humanity into his smallscale, low-rise housing blocks. This is perhaps one of the parameters of his designed environment, and it resembles Jane Jacobs's human-scale environment. Koolhaas's buildings view the city and become an attempt to observe that view without showing themselves. Possibly acquainted with the expectations and the fragments of the Amsterdam, Koolhaas created a node point in a city of flux such as Amsterdam.

OMA describes the plan as "isolation as idyll, isolation as protection, isolation as neglect, must be creatively solved and exploited in the plan". ${ }^{14}$ This isolation may have created a self-sustainable environment in its time, however, regarding long-term planning and sustainability ${ }^{15}$ approach in Vinex policies which emerged afterwards, IJ-plein can be lacking in achieving these (Figures 10, 11).

While displaying smart growth criteria such as sustainability, accessibility, mobility and as well as affordable housing, IJ-plein displays a still frame in order to examine and display what is changing in the environment reluctantly, when observed from today. Therefore, how does a building adapt to changing conditions in a rhizomatic city? A possible answer lies in the formation of an "imageless" pattern which constructs its own set of self-meanings and has a strategy for dealing with changing urban conditions over time. OMA's pattern lies in between. The human-scale approach and accessibility find meanings in perception. This is not an articulative but, rather, an imageless way of representing the loci where dwellers can embody space and find new meanings and collages. Koolhaas's relationship to the rhizome in the IJ-plein is arguably weak due to the lack of founding a relationship with the water and the rest of the city. Regarding today's needs and approach-

${ }^{13}$ Goldberger, 2000. $\quad{ }^{14}$ Jolles, $2003 . \quad{ }^{15}$ Boelens, 2010. 


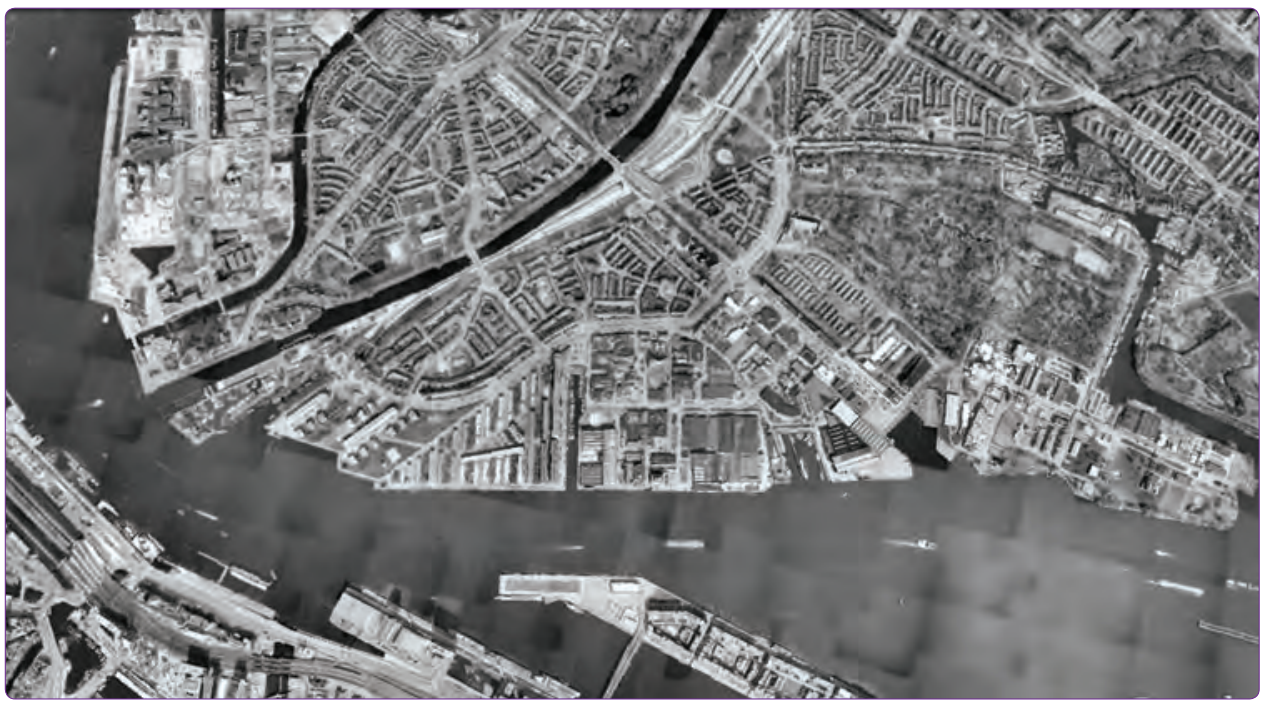

Figure 10. IJ-plein in 2015, Google Earth 6.0. (2015). 52 $22^{\prime} 57.3^{\prime \prime} \mathrm{N}, 4^{\circ} 55^{\prime} 00.3^{\prime \prime} \mathrm{E}$, http://www. google.com/earth/index.html [Accessed July 31, 2015].

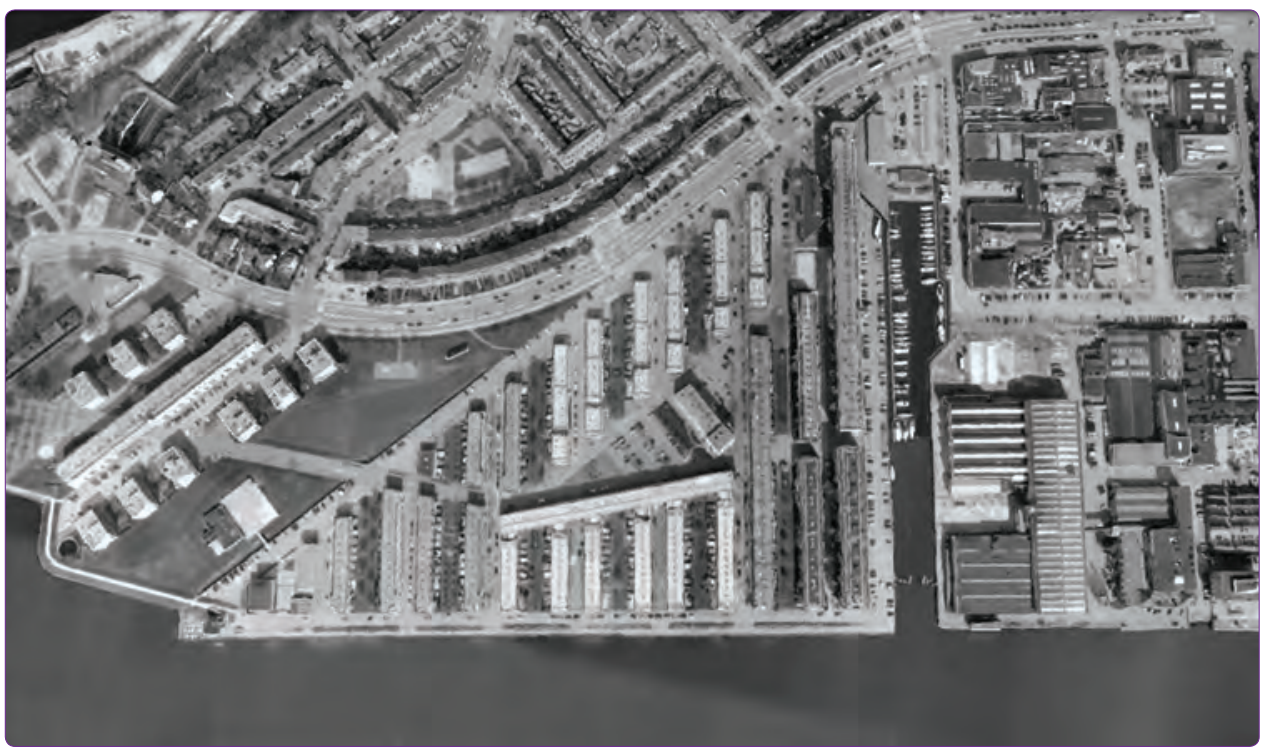

Figure 11. IJ-plein in 2015, Google Earth 6.0. (2015). 52²2'57.0", N 454'58.9"E, http://www. google.com/earth/index.html [Accessed July 31, 2015].

es in mixed-use residential waterfronts, it is culturally poor and unattractive to young residents. The design does not sufficiently provide mixed use, socially mixed housing, or open spaces. Regarding Amsterdam's existing high-density 101 housing units per hectare, Koolhaas's idea of attracting people through form is less likely to create communication. It creates a visual relationship over the IJ and a passive engagement with context. ${ }^{16}$ It is a universal narrative that changes the routes of the rhizome, but this is observed in his later works. His design in the IJ-plein is, rather, a residential area with a modern perception interpreting locality without taking risks. The area once had a strategic position with the potential to articulate the rhizomatic centre and extend it in a flexible strategy; however, there is a negative interpretation of the relationship with the water which is mentioned by the DRO. ${ }^{17}$

However, on the other hand, OMA's project is a fresh, modern approach with universal loci, but it also includes locality. Moreover, it epitomises the chang- 
es in policies in a city in flux, staying reluctant about change in urban policies and approaches. The area contains details that display an imageless condition in its own microcosm. However, regarding the zeitgeist of changing urban policies and conditions, this could be conducted at a different level with policies regarding density.

As a summary, IJ-plein's planning criteria refers to the smart growth development, which includes mixed land use within a sustainable and walkable urban environment. In a way, IJ-plein is an interpretation of lively human-scale cities, where there is a diversity of housing schemes in a multilayered urban structure.

\section{Acknowledgement}

I would like to thank NDSM Werf Museum for providing photographs.

\section{References}

Anon (a). 2014, http://static.nai.nl/oma/Start_EN/Start search. php? projectid $=67 \&$ subcat_van $=0 \&$ subcatid $=0$ [Accessed 2 June 20014].

Anon (b). 2014 "Urban Design IJ-Plein", http://www.architectureguide.nl/project/list_projects_of_architect/arc_ id/805/prj_id/382 [Accessed 2 June 2014].

Anon (c), 2014 "History of Eastern Docklands Amsterdam", http://www.amsterdamdocklands.com/navigation/Historie/Introduction-2.html [Accessed 8 June 2014].

Boelens, L. (2010) "Theorizing Practice and Practising Theory: Outlines for an Actor-Relational-Approach in Planning", Planning Theory 9 (1), p. 28-62. doi: 10.1177/1473095209346499.

Buurman, M. (2003) "KNSM Island", Eds.: J. E. Abrahamse et al. Eastern Harbour District Amsterdam: Urbanism and Architecture, Rotterdam, NAi Publishers, p. 58-59.

Christiaanse, K. (2003) "Housing in Harbours in Holland", disP-The Planning Review 39 (154), p. 4-10. doi:10.108 0/02513625.2003.10556850.

Deleuze, G. and Guattari, F. (1987) Thousand Plateaus: Capi- talism and Schizophrenia, trans. Brian Massumi, Minneapolis, University of Minnesota Press, p. 21.

Ensink, M. (2011) "Gebieds-en vastgoedontwikkeling. De strijd om kwaliteit en kwantiteit tussen markt en overheid in een economisch slechte tijd!", Master's thesis, Universiteit Van Amsterdam, Amsterdam, p. 63 http:// dare.uva.nl/document/358750 [Accessed 11 June 2014].

Gastil, R. (2002) Beyond the Edge: New York's New Waterfront, New York, Princeton Architectural Press, p. 64.

Goldberger, P. (2000) "The Architecture of Rem Koolhaas", Rem Koolhaas 2000 Laureate Essay, http://www.pritzkerprize.com/sites/default/files/file_fields/field_files_inline/2000_essay.pdf [Accessed 2 June 20014].

Graafland, A. (2000) The Socius of Architecture: Amsterdam, Tokyo, New York, Rotterdam, 010 Publishers, p. 105.

Graafland, A. (2012) "Amsterdam Housing, Dessau", DIA Series, 86, http://www.ariegraafland.eu/wp-content/ downloads/Amsterdam-Housing.pdf [Accessed 2 June 20014].

Jolles, A. (2003) Planning Amsterdam: scenarios for urban development, 1928-2003, Rotterdam, NAI Publishers, p. 145.

OMA (1988) "Masterplan of IJ-plein", Image, http://www. oma.eu/projects/1988/ij-plein-masterplan-school-andgymnasium/, [Accessed 11 October 20014].

Özdamar, E. G. (2011) “ Çağdaş konutun olay örgüsünü kentsel dinamikler bağlamında yeniden okuma: İstanbul, Viyana, Amsterdam", Unpublished PhD Thesis, Istanbul Technical University, Institute of Science and Technology.

Schaap, T. (2003) "Found object: The Urban Planning of the Eastern Harbour District", J. E. Abrahamse et al. Eastern Harbour District Amsterdam: Urbanism and Architecture, Rotterdam, NAi Publishers, p. 49-53.

van den Boomen, T. (2002) "Koolhaas's Eersteling", Bouw 57 (2), 16, http://www.tijsvandenboomen.nl/?page_ id=2\&mode=browse\&artikel_id=1004 [Accessed 2 June 20014].

van der Heijden, I. M. (2010) "Punctuated Equilibrium", Master's thesis, Technische Universiteit Eindhoven, Eindhoven, 9, http://alexandria.tue.nl/extra2/afstversl/ bwk/693386.pdf [Accessed 1 June 20014]. 